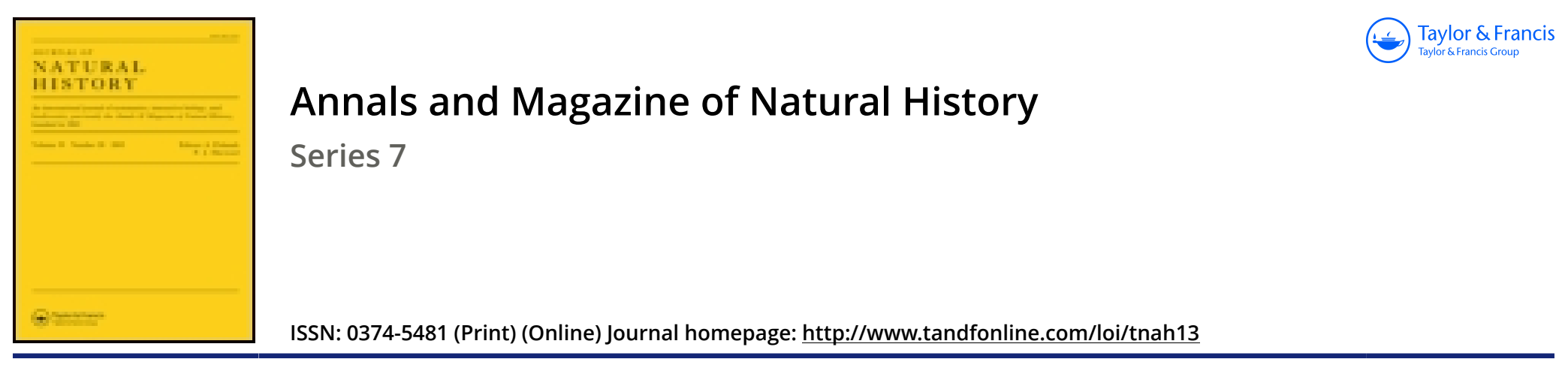

\title{
XXXVIII.—On the "Tohi," the East-African reedbuck currently known as Cervicapra bohor
}

\section{Oldfield Thomas}

To cite this article: Oldfield Thomas (1900) XXXVIII._On the "Tohi," the East-African reedbuck currently known as Cervicapra bohor, Annals and Magazine of Natural History, 6:33, 303-304, DOI: $10.1080 / 00222930008678379$

To link to this article: http://dx.doi.org/10.1080/00222930008678379

曲 Published online: 22 Sep 2009.

Submit your article to this journal $\lceil\pi$

Џ Article views: 4

Q View related articles $\asymp$ 


\section{XXXVIII.-On the "Tohi," the East-African Reedbuck cur- rently known as Cervicapra bohor. By Oldfield Thomas.}

MessRs. Rowland WARD have recently put into my hands three Reedbuck skulls which, collected some tiventy or thirty years ago, had become scattered into different collections, but which, noticing their peculiarity, Messis. Ward had kept in touch with and have now brought together again in order that I might examine and report upon them.

They were obtained in some part of the Upper Nile, and, according to one account, at Kassala. Their collector was a Herr Essler, by whom a number of other large mammals now in the British Museum were procured at the same time.

Their northern locality has still more recently been confirmed by Dr. Donaldson Smith, who obtained several specimens of the same form during his recent journey from Lake Rudolf to the Nile, in about $5^{\circ} \mathrm{N}$. latitude.

Now these specimens all agree among themselves, and differ from all the species recognized in the 'Book of Antelopes,' by the peculiar graceful curvature of their horns, which, while first sloping backwards and then outwards somewhat as in $C$. arundinum, are distinctly. (though not abruptly) recurved forwards and inwards terminally. As a result their back view is not altogether unlike the more distant figure of $C$. arundinum in the 'Book of Antelopes,' pl. xliii., though the tips approach each other terminally much more, while their side view is similar both to those of the East-African antelope currently known, since Dr. Günther's paper on the subject*, as $C$. bohor, and also to Ruppell's figure of "Antilope redunca" + , afterwards the type of his C. bohor.

The side view of the horn-curvature being therefore the same, Dr. Günther, in the absence of Abyssinian material, not unnaturally assigned the East-African animal, the "Tohi" of Mr. Jackson in 'Big Game Shooting;' to Rüppell's species; but it is now quite clear, both by locality and by some details about the type kindly sent me by Dr. Kobelt, that Messrs. Ward's specimens are the true Bohor, being the first examples of it that have come to this country. By their aid we see that it is a peculiar northern species, most nearly allied to $C$. arundinum, to which it approximates in size, but is distinguished by its terminally incurved and recurved horns.

* P. Z. S. 1890 , p. 604.

† N. Wirb. Abyss. pl. vii. fig. 1 (1835). 
A second name applicable to it is "Cervicapra? odrob," Heuglin *, based on an antelope observed by him on the River Setit.

But if this antelope, with its widely expanded semilyrate horns, is the true $C$. bohor, the question arises as to what is the proper appellation for the very different Reedbuck from East Africa which has of late been known by that name.

That animal, as is shown in the 'Book of Antelopes' $t$, is closely allied to the West-African Nagor (C. redunca, Pall.), being distinguished from it merely by its greater size, the difference there quoted being 9 inches as compared to 8 in the basal length of the skull.

A renewed comparison not only confirms the alliance of the two forms, but shows that the difference is even less than we then supposed; for Messrs. Ward, who had already helped so materially in this matter, have lent me the skull of an unusually fine Nagor which had been shot by Lieut. A. A. E. Ellison, R.N., 160 miles up the River Gambia, and this skull measured no less than 8.65 inches ( 220 millim.) in basal length, nearly as much as in ordinary East-African Reedbucks. The fur, at least of the bead, is closer and finer than that of East-African specimens, but is quite similar in colour.

These being the facts, it would appear better to treat the Tohi as a subspecies of $C$. redunca, and in recognition of the help received from Messrs. Ward I would suggest the name

\section{Cervicapra redunca Wardi, subsp. n.}

Size rather larger than in the typical subspecies, basal length of skull 9 inches or more. Hair coarser and shaggier. Colour similar.

Skull of the type (an old male) :-

Basal length 234 millim. ( $9 \cdot 2$ inches); greatest breadth $114(4 \cdot 48)$; muzzle to orbit $138(5 \cdot 45)$. Horns : length round curve in front $235(9 \cdot 25)$, circumference at base $146(5 \cdot 75)$, breadth across most distant points externally $190(7 \cdot 5)$, tip to tip $143(5 \cdot 6)$.

Hab. East Africa. Type from the Mau Plateau.

Type. Male (skin and skull). B.M. no. 0.8.15.1. Collected by Mr. F. J. Jackson. Presented by Mr. Rowland Ward. 